\title{
Power supply of industrial and residential urban areas through the use of secondary combustible and thermal energy resources
}

\author{
Jury Lavirko [0000-0002-1451-2176], Michael Taymarov², Rimma Akhmetova ${ }^{2 *}$ [0000-0003-3137-7727], \\ and Aigel Sabirzyanova ${ }^{2}$ [0000-0001-8510-9117] \\ ${ }^{1}$ Kazan State University of Architecture and Engineering, 420043, Zelenaya st., Kazan, Russia \\ ${ }^{2}$ Kazan State Power Engineering University, 420066, Krasnoselskaya st., Kazan, Russia
}

\begin{abstract}
The subject at hand is the technology of integrated use of secondary combustible and thermal energy resources of oil refining and petrochemicals for power supply and heat supply of industrial and residential urban areas. Currently, combustible secondary energy resources in petrochemicals in through hydrocarbon gases are burned in smokeless flares and technological candles without practical use in the electric and thermal energy industry. In the production of polyethylene, an average of $230 \mathrm{t} / \mathrm{h}$ of spent combustible gases is burned in a smokeless flare at an altitude of $105 \mathrm{~m}$ with useless dispersion of the resulting heat in the atmosphere. The heat of heated process water during cooling in cooling towers is uselessly dispersed in the atmosphere or leaves with contaminated spillways and non-return condensate into settling tanks without practical useful application. In the construction of new and the energy supply of existing industrial and residential facilities, there is a problem providing them with electric and thermal energy at low prices. The purpose of this study is to develop a technical solution on the technology of integrated use of secondary combustible and thermal energy resources of oil refining and petrochemicals for the electrical and thermal supply of industrial and residential urban areas.
\end{abstract}

Keywords: Energy, supply, combustible, secondary, gas turbine, thermal, pump.

\section{Introduction}

According to the published data for 2019 [1-3] in PAO Nizhnekamskneftekhim and PAO Kazanorgsintez, the target of burning waste gases on flares and candles was $5 \%$ of the volume of all gaseous hydrocarbon raw materials used in the technology. During deep processing of petrochemical raw materials, many secondary energy resources are being in the form of heat of discharge water, circulation water of cooling towers, the heat of satellite water, and non-return condensate [4]. PAO Nizhnekamskneftekhim receives wastewater with a temperature of $25 \ldots 40{ }^{\circ} \mathrm{C}$ in the amount of $30000 \mathrm{~m} 3 / \mathrm{h}$ to treatment facilities. The heat of this water is not used due to the lack of a comprehensive technical solution for

\footnotetext{
${ }^{*}$ Corresponding author: ahmetova rv@bk.ru
} 
converting this low-potential energy into the heat of heating water with a temperature of $130 \ldots 150^{\circ} \mathrm{C}$ [5]. The absence of using exhaust gases as a fuel for generating heat and electricity is due to their inconstant heat of combustion and their inconstant volumes. In this regard, the study and development of a technology for the integrated sharing of thermal and combustible secondary low-potential resources for electricity and heat for the energy supply of industrial and residential areas are relevant areas in the field of energy [6]. The disadvantage of using steam compression heat pumps to utilize cooling tower heat is the high electric power consumption per compressor drive of $630 \mathrm{~kW}$ for heat pump NT-3000. Electric power conversion factor is 4.76. The ABHM-1500 $\mathrm{P}$ absorption heat pump requires heating steam as well as cooling water. The heat of energy parameters of heat pump based on ABHM - $1500 \mathrm{P}$ are not produced. Therefore, efficiency could be calculated only in summer mode for cold production $+7{ }^{\circ} \mathrm{C}$.

In this article, a prerequisite for supplying industrial and residential urban consumers with electric and thermal energy through the use of combustible and thermal secondary resources was to solve the following problems:

1. Collection and analysis of the quantity of secondary combustible and thermal energy resources available at enterprises.

2. Development of integrated technology for combined use of secondary energy resources.

3. Development of a technological scheme for the integrated use of these resources.

4. Selection of equipment for the integrated resource utilization process diagram.

5. Calculation of thermal balances of integrated use of combustible and thermal secondary resources.

In this study, the aim is to develop a technical solution on the technology of integrated use of secondary combustible and thermal energy resources of oil refining and petrochemicals for electrical and thermal supply of industrial and residential urban areas [7].

\section{Methods and methods}

The research methodology is based on the analysis of the volumes of unused secondary gaseous combustible energy resources by the heat of combustion, the composition of combustible components [8]. The analysis of volumes of low-potential thermal energy resources in the form of wastewater, cooling water of the cooling tower, and the possibility of using these resources in the technology of utilization of combustible waste gases for power generation based on the application of steam and gas turbine cycles is carried out. Heat balances are calculated for the developed scheme of the integrated using secondary energy resources using Mathcad software. Energy equipment is selected based on the performed calculations of the thermal balance for the generation of electricity and thermal energy in quantities necessary for the energy supply of industrial and urban areas.

The subject of the research is the analysis of information on the types of oil refining and petrochemicals producing associated secondary energy carriers, technology, and technical implementation of the integrated joint use of combustible and thermal energy resources for power supply and heat supply of industrial and residential urban areas [9-14].

Primary information is given on characteristics of secondary combustible and thermal energy resources for petrochemical ethylene industries in Table 1.

It is seen from Table 1 that the values of the thermal power parameters and the volumes of the secondary energy resources differ quite markedly. Their use in the production of electricity and heat supply of industrial and residential urban areas is possible based on a combined technology of joint use as part of technical complexes, in which separate modules for the utilization of combustible and thermal secondary energy resources are functionally combined. Modules for utilization of combustible secondary resources are gas 
turbine and steam turbine plants with steam and water heating boilers, and modules for utilization of heat secondary energy resources are heat pumps.

Table 1.Characteristics of secondary energy resources in petrochemistry.

\begin{tabular}{|c|c|c|c|c|}
\hline \multirow{2}{*}{$\begin{array}{l}\text { Name of the } \\
\text { energy resource }\end{array}$} & \multicolumn{2}{|c|}{$\begin{array}{c}\text { Combustion value, } \\
\mathrm{Q}_{\mathrm{np}}\end{array}$} & \multirow{2}{*}{$\begin{array}{l}\text { Thermodynamics enthalpy, } \\
\mathrm{kJ} / \mathrm{kg}\end{array}$} & \multirow{2}{*}{$\begin{array}{c}\text { Average } \\
\text { resource } \\
\text { volume, MW }\end{array}$} \\
\hline & $\mathrm{kJ} / \mathrm{kg}$ & $\mathrm{kJ} / \mathrm{m}^{3}$ & & \\
\hline $\begin{array}{l}\text { Cooling water of } \\
\text { cooling towers at } \\
25^{\circ} \mathrm{C}\end{array}$ & & & 105 & 25 \\
\hline $\begin{array}{l}\text { Wastewater of } \\
\text { treatment facilities at } \\
27^{\circ} \mathrm{C}\end{array}$ & & & 114 & 100 \\
\hline \begin{tabular}{|l|} 
Non-refundable \\
condensate at $90^{\circ} \mathrm{C}$
\end{tabular} & & & 377 & 10 \\
\hline $\begin{array}{l}\text { Reverse heat satellite } \\
\text { water at } 95^{\circ} \mathrm{C}\end{array}$ & & & 399 & 20 \\
\hline $\begin{array}{l}\text { Waste flammable } \\
\text { factory gases }\end{array}$ & & 27255 & & 227 \\
\hline $\begin{array}{l}\text { A mixture of heavy } \\
\text { hydrocarbon gases }\end{array}$ & & 33369 & & 220 \\
\hline $\begin{array}{l}\text { Pyrolysis resins with } \\
\text { spent gasoline }\end{array}$ & 39300 & & & 10 \\
\hline $\begin{array}{l}\text { Liquid combustible } \\
\text { sorbent A-2 }\end{array}$ & 41636 & & & 23 \\
\hline $\begin{array}{l}\text { Methane-hydrogen } \\
\text { fraction }\end{array}$ & & 28526 & & 200 \\
\hline Petrol coke & 30180 & & & 200 \\
\hline $\begin{array}{l}\text { Reverse heat satellite } \\
\text { water at } 70^{\circ} \mathrm{C}\end{array}$ & & & 294 & 14.7 \\
\hline $\begin{array}{l}\text { Polycarbonate water } \\
\text { condensate at } 130^{\circ} \mathrm{C}\end{array}$ & & & 547 & 20 \\
\hline $\begin{array}{l}\text { Polycarbonate water } \\
\text { condensate at } 40^{\circ} \mathrm{C}\end{array}$ & & & 168 & 20 \\
\hline
\end{tabular}

\section{Results}

Analysis of data on types of secondary resources (see Table 1) makes it possible to conclude that using the heat of low potential heat carriers should be included in the modules of fuel secondary resources utilization. The developed functional diagram of the interaction of modules of fuel and heat secondary resources utilization is given in Fig. 1. 


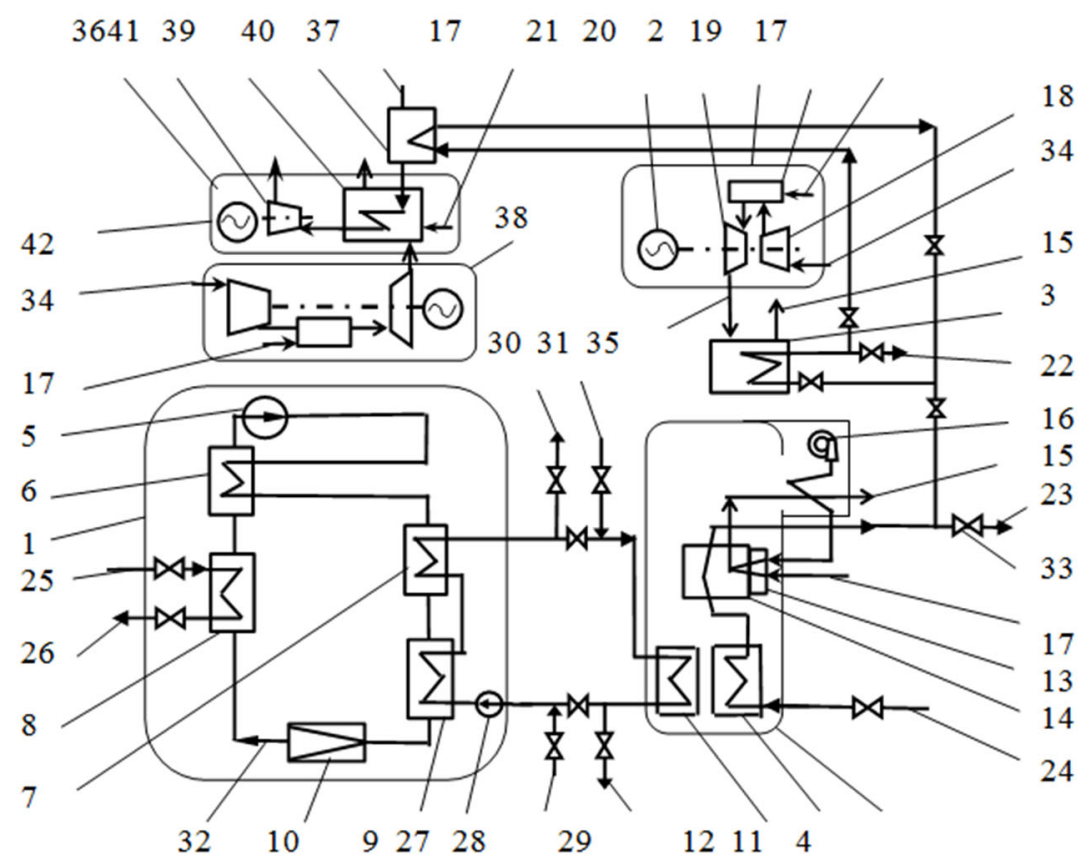

Fig. 1. Scheme of the complex for power supply of industrial and urban areas using secondary combustible and thermal low - potential energy resources: 1 - steam compression heat pump module, 2 - module of gas turbine plant with water heating boiler, 3 - hot water boiler, 4 - lithium bromide absorption heat pump module; 5 - piston compressor, 6 - regenerative heat exchanger, 7 - condenser, 8 - evaporator, 9 - sub cooler, 10 - throttle, 11 - absorber, 12 - evaporator heat exchanger, 13 generator furnace, 14 - furnace heat exchanger, 15 - flue gases, 16 - fan, 17 - secondary combustible gas, 18 -compressor axis, 19 - combustion chamber, 20 - gas turbine, 21 - electric generator of gas turbine plant, 22 - superheated heating water at $150^{\circ} \mathrm{C}, 23$ - heating water at $130^{\circ} \mathrm{C}, 24$ - return water at $70^{\circ} \mathrm{C}, 25$ - recycled water at $25^{\circ} \mathrm{C}, 26$ - recycled water at $5^{\circ} \mathrm{C}, 27$ - circulation pump, 28 - return water at $40^{\circ} \mathrm{C}, 29-$ chilled water at $10^{\circ} \mathrm{C}, 30$ - heated water at $70^{\circ} \mathrm{C}, 31-$ return water at $30^{\circ} \mathrm{C}, 32-$ coolant, 33 - gate valves, 34 - air to the compressor, 35 - combustion products after a gas turbine, 36 - steam turbine module with electric generator and steam boiler, 37 - feed water, 38 - gas turbine unit module with steam turbine cycle, 39 - steam boiler, 40 - feed water heater, 41 - steam turbine, 42 electric generator of a steam turbine unit.

In the diagram (see Fig. 1), module 1 of the steam compression heat pump uses lowpotential heat of large volumes of cooling water 25 with temperature of $25^{\circ} \mathrm{C}$. The heat recovery water 26 with a temperature of $5{ }^{\circ} \mathrm{C}$ can be used as a source of cold for in-plant consumption during the operation of air conditioners and cooling devices. The heat received in module 1 from the water 25 heats the return water 28 which, in the inter-module circulation cycle of the first embodiment, transfers this heat to the lithium bromide absorption heat pump module 4 through the heat exchanger 12 for primary heating of the water 24 in the absorber 11. In the inter-module cycle of the second embodiment, the primary heating of the water 24 in the absorber 11 is effected by supplying the return water 31 to the heat exchanger 12, from which, at closed gate valves on lines 28 and 29 and open line gate valve, water 31 is supplied by pump 27 for heating to condenser 7 and further in the form of heated water 30 with temperature $70^{\circ} \mathrm{C}$ at closed line gate valve is directed to consumers.

After primary heating in absorber 11, water 24 enters furnace heat exchanger 14 in which the heat is transferred from the flare generated by combustion in furnace 13 of discharge combustible gas 17 in admixture with air supplied by fan 16.The air is heated by 
the outgoing flue gases 15. After heating in the furnace heat exchanger 14, the heating water 23 having a temperature of $130^{\circ} \mathrm{C}$ is supplied to the boiler 3 , in which by supplying heat from the combustion products 35 , superheated heating water 22 having a temperature of $150^{\circ} \mathrm{C}$ is obtained. The module of the gas turbine unit 2 generates electric power by the combustion of the discharge secondary combustible gas 17 in the combustion chamber 19 , to which air 34 is supplied by the axial compressor 18 . The combustion products 35 , after expansion at the gas turbine 20, enter boiler 3 in which the heating water 22 is superheated. The mechanical rotation energy of the shaft of the gas turbine 20 is converted by the electric generator 21 into electric power transmitted to consumers. A part of the superheated heating water 22 at the temperature of $150{ }^{\circ} \mathrm{C}$ supplies to the feed water 37 supplied to the steam boiler 39 in which the discharge secondary combustible gas 17 burns in the heated combustion air mixture after the gas turbine of module 38 [15].

The steam boiler 39 generates superheated steam supplied to the steam turbine 41 , the mechanical rotation energy of which transmits to the electric generator 42 for power generation[16]. The combustion of the discharge secondary combustible gas 17 in the combustion chamber of module 38 allows electric power to be obtained by rotating the generator shaft from the gas turbine. The use of the inter-module steam turbine unit 36 with the boiler 3 allows the superheated heating water 22 to be used to heat the feed water $37[17]$. The efficiency of the gas turbine plant due to the steam turbine unit increases on average by $15 \ldots 20 \%$.

The developed complex (see Fig. 1) is technically implemented due to two industrial gas turbine power units GTE-2,5 with a single electric capacity of $2.5 \mathrm{MW}$. From them, one works with the UTO-4.5 boiler with a power of $2.5 \mathrm{MW}$, another - with the $4.5 \mathrm{MW}$ KGT 6/0.6-200 boiler. The module 1 of the steam compression heat pump technically consists of two series-connected steam compression heat pumps NT-3000 with a unit capacity of 3 MW. Module 4 of the lithium bromide absorption heat pump consists of two seriesconnected bromide-lithium machines ABHM Thermax with a unit capacity of 5.35 MW with direct combustion of discharge secondary combustible gas. The steam turbine module uses a TURBOPAR steam turbine with a $3 \mathrm{MW}$ electric generator [18-24].

\section{Discussion}

From the presented results (Table 2), it can be seen that the main share in the use of secondary energy resources falls on the generation of electricity due to the combustion of flammable gases when operating a universal system consisting of two GTE-2,5, two NT3000 and two ABHM Thermax and a steam turbine plant. The amount of electricity generated is $6.74 \mathrm{MW}$ while heating the heating water to temperature of $150^{\circ} \mathrm{C}$ in a volume of 12.7 MW for external consumers. The additional generation of heating water with a temperature of $70^{\circ} \mathrm{C}$ is $6.3 \mathrm{MW}$ [25-26]. The resulting cold water can be used with air temperatures of $5^{\circ} \mathrm{C}$ and $10{ }^{\circ} \mathrm{C}$ for process purposes and conditioning. The total available capacity of the complex for the utilization of secondary combustible and thermal energy resources consisting of two GTE-2,5, two NT-3000 and two ABHM Thermax and a steam turbine plant is $50.5 \mathrm{MW}$. The advantage of the developed complex (see Fig. 1) over the heat pumps, gas turbine plants, and recovery boilers used in single versions is the possibility of using inter-module cycles for the utilization of secondary combustible and thermal energy resources with significant changes in the volumes of secondary energy resources and their energy characteristics. This is achieved by the fact that each module has two different types of energy circulation circuits, in which the energy parameters of energy resources can vary widely. Besides, there is a standby inter-module cycle for heating water with a temperature from $40^{\circ} \mathrm{C}$ to $70^{\circ} \mathrm{C}$ (see items 30 and 31 of Fig. 1) [27]. 
Table 2. Energy balance of the complex for recycling of secondary energy resources of petrochemicals for power supply of industrial and urban areas.

\begin{tabular}{|c|c|c|c|c|}
\hline Income & & \multirow[b]{2}{*}{$\begin{array}{l}\text { Value, } \\
\text { MW }\end{array}$} & \multirow{2}{*}{$\begin{array}{c}\text { Expense } \\
\text { Type of } \\
\text { energy supply }\end{array}$} & \multirow[b]{2}{*}{$\begin{array}{l}\text { Value, } \\
\text { MW }\end{array}$} \\
\hline Type of energy supply & & & & \\
\hline \multicolumn{5}{|c|}{ Gas turbine unit module with steam turbine cycle } \\
\hline $\begin{array}{c}\text { Heat from the combustion } \\
\text { of waste gas }\end{array}$ & 10 & $\begin{array}{l}\text { Electric power } \\
\text { to consumers }\end{array}$ & 2.5 & $\begin{array}{l}\text { Heat from the } \\
\text { combustion } \\
\text { of waste gas }\end{array}$ \\
\hline & & $\begin{array}{l}\text { Heat with gases } \\
\text { in steam boiler }\end{array}$ & 6.3 & \\
\hline & & Heat loss & 1.2 & \\
\hline $\begin{array}{c}\text { Total energy } \\
\text { resources received }\end{array}$ & 10 & $\begin{array}{c}\text { Total energy } \\
\text { resources consumed }\end{array}$ & 10 & $\begin{array}{c}\text { Total energy } \\
\text { resources received }\end{array}$ \\
\hline \multicolumn{5}{|c|}{ Steam turbine module with electric generator and steam boiler } \\
\hline $\begin{array}{l}\text { The heat from the } \\
\text { combustion of waste gas }\end{array}$ & 1.7 & $\begin{array}{l}\text { Electric power } \\
\text { to consumers }\end{array}$ & 3.0 & $\begin{array}{l}\text { The heat from the } \\
\text { combustion } \\
\text { of waste gas }\end{array}$ \\
\hline $\begin{array}{c}\text { Heat supplied } \\
\text { with water at } 150^{\circ} \mathrm{C}\end{array}$ & 1.2 & Heat loss & 2.2 & $\begin{array}{c}\text { Heat supplied } \\
\text { with water at } 150^{\circ} \mathrm{C}\end{array}$ \\
\hline $\begin{array}{l}\text { Heat with gases } \\
\text { after the turbine }\end{array}$ & 6.3 & $\begin{array}{c}\text { Heat leaving } \\
\text { with condensate }\end{array}$ & 4.0 & $\begin{array}{l}\text { Heat with gases } \\
\text { after the turbine }\end{array}$ \\
\hline $\begin{array}{c}\text { Total energy } \\
\text { resources received }\end{array}$ & 9.2 & $\begin{array}{c}\text { Total energy } \\
\text { resources consumed }\end{array}$ & 9.2 & $\begin{array}{c}\text { Total energy } \\
\text { resources received }\end{array}$ \\
\hline \multicolumn{5}{|c|}{ Gas turbine unit module with hot water boiler } \\
\hline $\begin{array}{c}\text { Heat from the combustion } \\
\text { of waste gas }\end{array}$ & 10 & \begin{tabular}{|c|} 
Electric power \\
for steam \\
compression module
\end{tabular} & 1.26 & $\begin{array}{l}\text { Heat from the } \\
\text { combustion } \\
\text { of waste gas }\end{array}$ \\
\hline $\begin{array}{c}\text { Heat supplied } \\
\text { with water at } 130^{\circ} \mathrm{C}\end{array}$ & 7.0 & $\begin{array}{l}\text { Electric power } \\
\text { to consumers }\end{array}$ & 1.24 & $\begin{array}{c}\text { Heat supplied } \\
\text { with water at } 1300^{\circ} \mathrm{C}\end{array}$ \\
\hline & & $\begin{array}{c}\text { Heat of water heating } \\
\text { to } 150^{\circ} \mathrm{C}\end{array}$ & 13.9 & \\
\hline & & Heat loss & 0.6 & \\
\hline $\begin{array}{c}\text { Total energy } \\
\text { resources received }\end{array}$ & 17.0 & $\begin{array}{c}\text { Total energy } \\
\text { resources consumed }\end{array}$ & 17.0 & $\begin{array}{c}\text { Total energy } \\
\text { resources received }\end{array}$ \\
\hline \multicolumn{5}{|c|}{ Steam compression heat pump module } \\
\hline Power consumption & 1.26 & $\begin{array}{l}\text { Water heating up to } \\
70^{\circ} \mathrm{C}, \mathrm{MW}\end{array}$ & 6.3 & Power consumption \\
\hline $\begin{array}{c}\text { Heat of cooling water at } \\
25^{\circ} \mathrm{C}\end{array}$ & 5.74 & Heat loss & 0.7 & $\begin{array}{l}\text { Heat of cooling } \\
\text { water at } 25^{\circ} \mathrm{C}\end{array}$ \\
\hline $\begin{array}{c}\text { Total energy } \\
\text { resources received }\end{array}$ & 7.0 & $\begin{array}{c}\text { Total energy } \\
\text { resources consumed }\end{array}$ & 7.0 & $\begin{array}{c}\text { Total energy } \\
\text { resources received }\end{array}$ \\
\hline \multicolumn{5}{|c|}{ Absorption heat pump module } \\
\hline $\begin{array}{c}\text { Heat from combustion } \\
\text { of waste gas }\end{array}$ & 5 & $\begin{array}{c}\text { Heat of water } \\
\text { heating to } 130^{\circ} \mathrm{C}\end{array}$ & 7.0 & \begin{tabular}{|c|}
$\begin{array}{c}\text { Heat from combustion } \\
\text { of waste gas }\end{array}$ \\
\end{tabular} \\
\hline $\begin{array}{l}\text { Heat with incoming } \\
\text { water at } 70^{\circ} \mathrm{C}\end{array}$ & 2.3 & Heat loss & 0.3 & $\begin{array}{c}\text { Heat with } \\
\text { incoming water at } 70^{\circ} \mathrm{C}\end{array}$ \\
\hline $\begin{array}{c}\text { Total energy } \\
\text { resources received }\end{array}$ & 7.3 & $\begin{array}{l}\text { Total energy } \\
\text { resources consumed }\end{array}$ & 7.3 & $\begin{array}{l}\text { Total energy } \\
\text { resources received }\end{array}$ \\
\hline $\begin{array}{l}\text { Total received by the } \\
\text { complex }\end{array}$ & 50.5 & \begin{tabular}{|c|} 
Total consumed by the \\
complex
\end{tabular} & 50.5 & $\begin{array}{l}\text { Total received by the } \\
\text { complex }\end{array}$ \\
\hline
\end{tabular}




\section{Conclusions}

1. The created heat pump complex allows to disposal of secondary combustible and thermal energy resources in quantities sufficient for the generation of cheap electricity and heat for heating of heating water at a power supply of industrial and residential urban areas.

2.The advantage of the developed complex over other methods of utilization of waste combustible gases and low-potential heat of cooling water and discharge effluents is the presence of inter-module circulation circuits different in types of energy resources, which allow simultaneously using energy resources that differ in temperature level and method of utilization.

The result is the development of a technical solution that allows petrochemical enterprises to dispose of combustible and thermal energy resources of any volume with the generation of electric and thermal energy useful for practical application while changing their ratio in a fairly wide range.

\section{References}

1. Report on the sustainable development of NC Taif, 2019 Electronic resource. URL: kgo.rcb.ru 2019 //nizhnekamskneftehimsocial.pdf.

2. REGNUM News Agency. Electronic resource. URL: regnum.ru〉news/26965.html (last accessed 25.03.2021)

3. Business electronic newspaper of Tatarstan «Business online»: Electronic resource. URL: business-gazeta.ru/news/315798 (last accessed 25.03.2021)

4. E. Jeffs, Gas turbine engineer ahead of his time, Gas Turbine World, E 5 (2016)

5. D. Chase, Combined Cycle development evolution and future, GE Power Systems, E 4 (2020)

6. R. Alff, Economics of Heavy Fuels in Gas Turbines, ASME Paper, E 3 (2019).

7. D. Hisajima, Determination of Thermal Properties of Dilute LiBr-Water Solutions, Int. J. of Thermophysics, 18, E 2, 397-406 (2019) DOI: 10.1007/BF02575170

8. S. Uchida, Low temperature absorption refrigeration machine with water-LiBr mixed refrigerant, Japan, Refrigeration, 81, E 946, 18-621 (2016)

9. Z.Y. Xu, Absorption refrigeration cycles:Categorized based on the cycle construction, Int. J. of Refrigeration, 62, 114-136 (2016) DOI:10.1016/j.ijrefrig.2015.10.007

10. R. Z. Wang, Experimental evaluation of avariable effect LiBr-water absorption chiller designed for high-efficient solar cooling system, Int. J. of Refrigeration, 69, 135-143 (2017) DOI:10.1016/j.ijrefrig.2015.07.019

11. S. Pedersen, $18 \mathrm{MW}$ heat pump plant utilising low-potential waste water heat, Thermal pumps thermal pumps, E 1, 36-37, (2018)

12. D. Nakamura, Global ethylene capacity increases slightly, Oil and Gas Journal, 105, E 27, 45-48 (2017)

13. J. H. Sung, Novel absorption refrigeration system with a hollow fiber membrane-based generator, Int. J. of Refrigeration, 71, 418-432 (2018) DOI: 10.1016/j.ijrefrig.2016.04.012

14. F. Ziegler, Experimental performances of a LiBr-water absorption facility equipped with adiabatic absorber, Int. J. of Refrigeration, 74, 1749-1759 (2019) DOI: 10.1016/j.ijrefrig.2011.07.014

15. J. Francois, Estimation of the energy efficiency of a wood gasification CHP plant using, Aspen Plus, Chemical engineering transactions, E 29, 769-774 (2012) DOI: 10.3303/CET1229129 
16. K. Jinhyun, Theoretical analysis of thermal performance in a plate type liquid heat exchanger, Applied Thermal Engineering, 108, 1020-1032 (2016) DOI: 10.1016/j.applthermaleng.2016.07.196

17. O. B. Barysheva, R. A. Sadykov, N. Y. Batyushkov, Optimization of the routing of the low-pressure gas distribution network, Modern construction and architecture, E 3, 2528 (2016)

18. M. Beckmann, F. Klepmann, J. Martin, R. Scholz, Classification of Waste-to-energy Plants in Terms of Energy Recovery, VGB PowerTech, E 10, 76-81 (2017)

19. Y. Shen, K. Yoshikawa, Recent progresses in catalytic tar elimination during biomass gasification or pyrolysis, Renewable and Sustainable Energy Reviews, E21, 371-392 (2013), DOI: 10.1016/j.rser.2012.12.062

20. J. Chung, An experimental evaluation of an integrated biomass gasification and power generation system for distributed power applications, Applied Energy, E 10, 699-708 (2018) DOI: 10.1016/j.apenergy.2012.07.036.

21.X. Liu, Calcium Methoxide as a Solid Base Catalyst for the Transesterification of Soybean Oil to Biodiesel with Methanol, Fuel, 87, 1076-1082 (2008) DOI: 10.1016/j.fuel.2007.05.059

22. B. Russbueldt, New Rare Earth Oxide Catalysts for the Transesterification of Triglycerides with Methanol Resulting in Biodiesel and Pure Glycerol, Journal of Catalysis, 27, 290-304 (2010) DOI: doi.org/10.1016/j.jcat.2010.02.005

23. A. Demirbas, Biodiesel: a Realistic Fuel Alternative for Diesel Engines, London : Springer-Verlag London Limited, 209 (2018), DOI: 10.1007/978-1-84628-995-8

24. M. Balat, Significance of LPG in Turkish Vehicular Transpotation, Energy Sources, $\mathbf{E}$ 27, 485-488 (2005), DOI: 10.1080/00908310490449216

25. G. M. Akhmerova, R. G. Safiullin, Use of modern laboratory base in training of masters of profile «Heat and gas supply and ventilation systems», Vestnik Volgogradskogo gosudarstvennogo arhitekturno-stroitel'nogo universiteta. Seriya: Stroitel'stvoi arhitektura [Bulletin of Volgograd State University of Architecture and Civil Engineering. Series: Civil Engineering and Architecture], 3(80), 191-199 (2020)

26. G. M. Akhmerova, A. R. Zalyalova, R. M. Mukhametshina, Impact of soil moisture on heat losses of pipelines of district heat supply networks at underground channel-free gasket, International Scientific Conference on Socio-Technical Construction and Civil Engineering, (2020), DOI: 10.1088/1757-899X/890/1/012153

27 M. A. Taymarov, R. V. Akhmetova, E. A. Akhmetov, A. S. Sabirzyanova, Research of operation the parameters in the boiler TGMP-204HL at burning gas, IOP Conference Series: Materials Science and Engineering, 1089. 1, 012008 (2021) DOI: 10.1088/1757$899 X / 1089 / 1 / 012008$ 